University of Nebraska - Lincoln

DigitalCommons@University of Nebraska - Lincoln

Faculty Papers and Publications in Animal

Science

Animal Science Department

$10-14-2004$

\title{
Heterosis for Grain Yield and Other Agronomic Traits in Foxtail Millet
}

\author{
M. M. Siles \\ University of Nebraska-Lincoln \\ William K. Russell \\ University of Nebraska-Lincoln, krussell3@unl.edu \\ Lenis Alton Nelson \\ University of Nebraska-Lincoln, Inelson1@unl.edu \\ David D. Baltensperger \\ Panhandle Research and Extension Center, University of Nebraska - Lincoln, Scottsbluff, NE, \\ dbaltensperger@tamu.edu \\ Blaine Johnson \\ Pioneer Hi-Bred Int.
}

See next page for additional authors

Follow this and additional works at: https://digitalcommons.unl.edu/animalscifacpub

Part of the Animal Sciences Commons

Siles, M. M.; Russell, William K.; Nelson, Lenis Alton; Baltensperger, David D.; Johnson, Blaine; Van Vleck, L. Dale; Jensen, Stanley G.; and Hein, Gary L., "Heterosis for Grain Yield and Other Agronomic Traits in Foxtail Millet" (2004). Faculty Papers and Publications in Animal Science. 156.

https://digitalcommons.unl.edu/animalscifacpub/156

This Article is brought to you for free and open access by the Animal Science Department at DigitalCommons@University of Nebraska - Lincoln. It has been accepted for inclusion in Faculty Papers and Publications in Animal Science by an authorized administrator of DigitalCommons@University of Nebraska Lincoln. 


\section{Authors}

M. M. Siles, William K. Russell, Lenis Alton Nelson, David D. Baltensperger, Blaine Johnson, L. Dale Van Vleck, Stanley G. Jensen, and Gary L. Hein 


\title{
Heterosis for Grain Yield and Other Agronomic Traits in Foxtail Millet
}

\author{
M. M. Siles, W. Ken Russell, David D. Baltensperger,* Lenis A. Nelson, Blaine Johnson, \\ L. Dale Van Vleck, S. G. Jensen, and Gary Hein
}

\begin{abstract}
Foxtail millet [Setaria italica (L.) P. Beauv.] is a largely selfpollinating species that is used as a warm-season annual in the USA. Nearly all cultivars of this species grown in the USA are selections from land races. This research was undertaken to determine whether sufficient high-parent heterosis is expressed in foxtail millet for grain yield and other key traits to justify the development and use of varietal crosses. Seven diverse parents and $21 F_{2} s$ and $21 F_{3}$ s produced from biparental crosses were evaluated in five environments in 1996. Genotype $\times$ environment interaction was highly significant for grain yield, but the highest yielding entries were high-yielding in each environment. High-parent heterosis for grain yield was detected in 18 of $21 F_{2}$ s. On the basis of the estimate of average heterosis, which was highly significant in every environment, the expected yield of the $F_{1}$ generation was $68 \%$ greater than the average yield of the parental cultivars. This high level of heterosis for grain yield suggested that varietal crosses or other types of cultivars in which there exists a relatively high amount of heterozygosity would provide a significant yield benefit over nonhybrid cultivars. Although significant heterotic effects were observed for each of the other traits, additive effects were more important. Significant correlations between traits of the estimates of additive and/or variety heterosis effects suggested that at least some of the genes controlling grain yield, plant height, and spike length were either the same or in coupling phase linkage.
\end{abstract}

$I^{N}$ THE GREAT PLAINS OF THE USA, foxtail millet is used primarily as a warm-season annual forage. The USDA has not released any estimates of land area planted to foxtail millet. However, it is often included in wheat-continuous crop rotations, which in some environments have been shown to be superior to the more traditional wheat-fallow rotations (Senft 1998). The grain of foxtail millet also is harvested for pet birdseed, and in China, India, and other parts of East Asia this species has been an important food crop for centuries.

Foxtail millet is largely a self-pollinating species. Outcrossing rates have been estimated from 0.0 to only $1.4 \%$ for plants separated by $0.30 \mathrm{~m}$ (Till-Bottraud et al., 1992), although Li et al. (1935) reported rates as high as $5.6 \%$ for some varieties under certain conditions. Nearly all foxtail millet cultivars grown in the USA are selections from land races. A primary reason that

M.M. Siles, D.D. Baltensperger, and G. Hein, Panhandle Research and Extension Center, Univ. of Nebraska-Lincoln, Scottsbluff, NE 69361-4939; W.K. Russell and L.A. Nelson, Dep. of Agronomy and Horticulture, Univ. of Nebraska-Lincoln, Lincoln, NE 68583-0915; B. Johnson, Pioneer Hi-Bred Int., 19456 State Hwy. 22, Mankato, MN 56001; L.D. Van Vleck, Dep. of Animal Science, Univ. of NebraskaLincoln, Lincoln, NE 68583-0908; S.G. Jensen, Dep. of Plant Pathology, Univ. of Nebraska-Lincoln, Lincoln, NE 68583-0722. A contribution of the Univ. of Nebraska Agricultural Research Division, Lincoln, NE 68583. Received 20 Aug. 2003. *Corresponding author (dbaltensperger1@unl.edu).

Published in Crop Sci. 44:1960-1965 (2004).

(c) Crop Science Society of America

677 S. Segoe Rd., Madison, WI 53711 USA varietal crosses or selfed selections from planned crosses have not been widely used is that foxtail millet is one of the most difficult species to cross-pollinate (Baltensperger, 1996). The flowers are small (about $1 \mathrm{~mm}$ in length), and anthesis generally occurs near midnight and in the morning but varies greatly with the environment (Malm and Rachie, 1971). However, Siles et al. (2001) described an artificial technique of hybridization that resulted in $67.5 \%$ hybrid seed set per flower crossed. Also, Wang (1991) reported the discovery of male-sterile varieties of foxtail millet. The ability to hybridize foxtail millet opens other options to breeders besides selecting from land races. If nonadditive gene action is important, then either mid- and/or high-parent heterosis may be sufficient to justify the production and use of varietal crosses.

Information on the inheritance of important agronomic traits of foxtail millet, including susceptibility to key diseases, is limited. Most of the previous work has focused on estimating broad-sense heritabilities and realized genetic gains, with little attention directed to measuring levels of heterosis or to assessing the relative importance of different types of gene action (Athwal and Singh, 1966; Singh and Athwal, 1966; Gill and Randhawa, 1975; Vishwanatha et al., 1981; Gurunadha Rao et al., 1984; Prasada Rao et al., 1985). Darmency et al. (1987) reported that most of 19 morphological and reproductive traits were probably under the control of nonadditive genetic components, but this research was conducted on an interspecific cross between foxtail millet and its wild relative $S$. viridis (L.) P. Veauv. Also, information on the importance of genotype $\times$ environment interaction for this species when grown in environments of the Great Plains is lacking.

Important agronomic traits in foxtail millet include not only grain yield, days to heading, days to maturity, and plant height, but also number of tillers and spike length. When foxtail millet is used as a forage, tillering is a desirable trait. However, nontillering cultivars are preferred for use in producing birdseed because the seeds typically are larger. Spike length also is correlated with seed size. One of the more important diseases affecting foxtail millet is leaf spot, which is caused by at least three species of Helminthosporium spp., H. setariae Sawada, H. turcicum Pass., and H. carbonum Ullstrup (Haenseler, 1941; Robert, 1962).

The objective of this research was to determine the presence and importance of heterosis for grain yield and other important agronomic traits of foxtail millet. Also, the relative importance of genotype $\times$ environmental effects and the interaction of heterosis with these effects were measured. This information is needed by breeders to determine the best types of cultivars to develop and to design testing programs with appropriate numbers and types of environments. 


\section{MATERIALS AND METHODS}

Two cultivars (Red Siberian and Golden German) and five plant introductions (PI614814, PI614815, PI614816, PI614817, and PI614818) were selected as parents for this study. The two cultivars were randomly chosen from many early cultivars that were introduced into and cultivated in the USA. The five plant introductions were selections from PI458628, PI531445, PI473598, NESE2, and PI464233, respectively, that matured in western Nebraska and on the basis of evaluations in the Nebraska Panhandle from 1991 to 1994 showed above average grain yield and resistance to Wheat streak mosaic virus (Siles et al., 2001).

In the summer of 1994, the parents were crossed in a halfdiallel arrangement to produce $21 \mathrm{~F}_{1}$ progenies. Seed of the $F_{2}$ and $F_{3}$ generations of each cross was produced in a greenhouse at the University of Nebraska-Lincoln in the winter of 1994 and summer of 1995, respectively. The $F_{3}$ generation of each cross was obtained by mixing equal quantities of seed from each of $200 \mathrm{~F}_{2}$ plants. In the summer 1996, the $F_{2}$ and $\mathrm{F}_{3}$ generations from each of the 21 crosses were evaluated in five environments in western Nebraska, in a split-plot design with two replications per environment. The main plots were the generations, and the subplots were the crosses. The seven parents were included in all replications of each main plot. Seed of a parent was produced by self-pollinating a single plant in the same environment as seed of the generation $\left(\mathrm{F}_{2}\right.$ or $\left.\mathrm{F}_{3}\right)$ of the main plot in which the parent was grown.

Four environments (E1 through E4) were located at the High Plains Agricultural Laboratory at Sidney, NE, and one environment (E5) was at the Panhandle Research and Extension Center at Scottsbluff, NE. E1 through E3 were dryland sites, whereas E4 and E5 were irrigated. The soil types were keith loam (fine-silty, mixed, mesic Aridic Argiustolls) at E1 and E4, duroc loam (fine-silty, mixed, mesic Pachic Haplustolls) at E2 and E3, and tripp fine sandy loam (coarse-silty, mixed, mesic Aridic Haplustolls) at E5. Sunflower (Helianthus annuus L.), fallow, wheat (Triticum aestivum L.), corn (Zea mays L.), and amaranth (Amaranthus spp.) were the previous crops at E1, E2, E3, E4, and E5, respectively. Sowing dates were 3 June, 22 May, 5 June, 5 June, and 4 June at E1, E2, $\mathrm{E} 3, \mathrm{E} 4$, and E5, respectively. The plot size was four rows by $2.1 \mathrm{~m}$ in length at E1, E2, and E3 or four rows by $1.5 \mathrm{~m}$ in length at E4 and E5. Adjacent rows within and between adjacent plots were spaced $0.3 \mathrm{~m}$ apart. All entries were planted at an average rate of $5.7 \mathrm{~kg}$ of seed ha ${ }^{-1}$.

Days to heading and maturity, grain yield, plant height, spike length, and number of tillers per plant were recorded at each environment. Days to heading and maturity were recorded on a plot basis and were counted from the date of plant- ing until $50 \%$ of the spikes emerged from the flag leaf and until the spikes turned pale yellow, respectively. Plant height, spike length, and number of tillers per plant were recorded as the mean of 10 randomly selected plants from the central two rows of each plot. Plant height and spike length were evaluated on the main culm, whereas the number of tillers per plant was recorded as the number of seed-bearing tillers per plant. The two central rows from each plot were harvested to evaluate grain yield. At E1, E2, and E3 only the middle $1.5 \mathrm{~m}$ section of each row was harvested; at E4 and E5 the middle $2.1 \mathrm{~m}$ of each row was harvested. Evaluations of resistance to Helminthosporium leaf spot were performed only at E3 and E4, where natural levels of infection were sufficiently high to discern differences among entries. The disease reaction was rated subjectively on a plot basis by a 10 -class scale $(0=$ no lesions at all or traces; $9=$ lesions on $90 \%$ or more of leaf surface on all plants). Disease reaction was scored at the flowering stage.

For each trait, an analysis of variance over all entries and across all environments was used to assess the relative importance of the environmental main effect and the interaction between environments and entries. Entries were treated as a fixed effect, whereas environments were treated as a random variable. The reference environmental space included both irrigated and dryland production sites in the high plains region of the Nebraska Panhandle and adjacent areas of Colorado and Wyoming with similar soil types, climate, and production practices. Additive $\left(a_{i}\right)$ and heterotic $\left(h_{i j}\right)$ effects were estimated for each variety $(i)$ and variety cross $(i j)$ and the heterotic effects were partitioned into average $(\bar{h})$, variety $\left(h_{i}\right)$, and specific $\left(s_{i j}\right)$ heterosis as described by Gardner and Eberhart (1966). The $F_{1}$ crosses were not grown and evaluated due to a shortage of seed, but an estimate of the performance of the $\mathrm{F}_{1}$ generation across all crosses was obtained as $\mu+\bar{h}$, where $\mu$ is the mean of the parental varieties. An estimate of the $F_{1}$ between the $i$ th and $j$ th parents was obtained as $\mu+a_{i}+a_{j}+$ $\bar{h}+h_{i}+h_{j}+s_{i j}$. Significance of the microenvironmental difference within environments between $\mathrm{F}_{2}$ and $\mathrm{F}_{3}$ whole plots was determined by an $F$ test in an analysis of variance of parental data only.

\section{RESULTS}

The environmental difference between whole plots within environments was not statistically significant $(p>$ $0.05)$; consequently, no corrections were made for this effect. Across environments, highly significant $(p<0.01)$ variation occurred among environments and entries for each trait (Table 1). For grain yield, the highest yielding

Table 1. Mean squares from an analysis of variance of data on seven agronomic traits measured on seven cultivars of foxtail millet and their half-diallel derived $21 F_{2}$ and $21 F_{3}$ progenies. Reaction to leaf spot was evaluated in two environments in 1996, and all other traits were evaluated in five environments in 1996.

\begin{tabular}{|c|c|c|c|c|c|c|c|c|c|}
\hline Source of Variation & df & $\begin{array}{l}\text { Grain } \\
\text { yield }\end{array}$ & $\begin{array}{l}\text { Days to } \\
\text { heading }\end{array}$ & $\begin{array}{l}\text { Days to } \\
\text { maturity }\end{array}$ & $\begin{array}{c}\text { Plant } \\
\text { height }\end{array}$ & $\begin{array}{c}\text { Spike } \\
\text { length }\end{array}$ & $\begin{array}{c}\text { Tillers } \\
\text { per plant }\end{array}$ & df & $\begin{array}{c}\text { Reaction to } \\
\text { leaf spot } \\
\text { disease }\end{array}$ \\
\hline & & $\left(\mathrm{Mg} \mathrm{ha}^{-1}\right)^{2}$ & 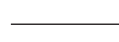 & - & $\longrightarrow$ & - & number $^{2}$ & & $(\operatorname{score} \dagger)^{2}$ \\
\hline Environments (Env) & 4 & $139.7^{* * *}$ & $1308.1^{* * *}$ & $1818.3 * *$ & $43032 * *$ & $136.5 * *$ & $18.7 * *$ & 1 & $10.2 * *$ \\
\hline Entries (Ent) & 48 & $2.6^{* *}$ & $180.3^{* *}$ & $112.4^{* *}$ & $777 * *$ & $90.7 * *$ & $10.0^{* *}$ & 48 & $20.4^{* *} *$ \\
\hline Additive effect & 6 & $4.7 * *$ & $1010.5 * *$ & $667.8 * *$ & $4589 * *$ & 434.6** & $76.7 * *$ & 6 & $145.7 * *$ \\
\hline Average heterosis & 1 & $59.4 * *$ & $645.9 * *$ & $150.3^{* *}$ & $2101 * *$ & $887.7 * *$ & $6.9 * *$ & 1 & $<\mathbf{0 . 1}$ \\
\hline Variety heterosis & 6 & $3.8^{* * *}$ & $114.8^{* * *}$ & 70.1 $* *$ & $492 * *$ & 82.6** & 0.1 & 6 & 2.2 \\
\hline Specific heterosis & 14 & 0.3 & 63.6** & 42.1** & 87 & $20.0 * *$ & $<0.1$ & 14 & $4.3 * *$ \\
\hline Residual & 21 & 0.3 & 17.5* & 10.9 & $166^{* * *}$ & $4.0^{*}$ & $0.7 * *$ & 21 & 1.4 \\
\hline Ent $\times$ Env & 192 & $0.4^{* *}$ & $9.3^{* * *}$ & $9.0 * *$ & $66^{* * *}$ & $2.4^{* *}$ & $0.2 * *$ & 48 & 0.9 \\
\hline Error & 240 & 0.2 & 1.9 & 2.3 & 37 & 1.3 & $<\mathbf{0 . 1}$ & 96 & 0.7 \\
\hline
\end{tabular}

* Significant at the 0.05 level of probability.

** Significant at the 0.01 level of probability.

$\dagger$ A 0-to-9 visual rating scale was used, with a score of 0 indicating no disease lesions and a score of 9 indicating lesions covering at least $90 \%$ of the leaf surface. 
Table 2. Means of seven foxtail millet cultivars for seven agronomic traits. Values for disease scores are averages across two environments in 1996 and for all other traits are averages across five environments in 1996.

\begin{tabular}{|c|c|c|c|c|c|c|c|}
\hline Parental cultivar & Grain yield & $\begin{array}{l}\text { Days to } \\
\text { heading }\end{array}$ & $\begin{array}{l}\text { Days to } \\
\text { maturity }\end{array}$ & $\begin{array}{l}\text { Plant } \\
\text { height }\end{array}$ & $\begin{array}{l}\text { Spike } \\
\text { length }\end{array}$ & $\begin{array}{c}\text { Tillers } \\
\text { per plant }\end{array}$ & $\begin{array}{c}\text { Leaf spot } \\
\text { disease }\end{array}$ \\
\hline & $\mathbf{M g ~ h a}^{-1}$ & d & & cm & & number & score $\dagger$ \\
\hline Golden German & 2.54 & 64.2 & 94.5 & 98.4 & 14.4 & 2.5 & 1.4 \\
\hline PI614814 & 2.75 & 62.2 & 90.2 & 99.6 & 9.4 & 0.0 & 2.0 \\
\hline PI614815 & 3.79 & 51.5 & 81.6 & 96.4 & 9.9 & 2.7 & 1.4 \\
\hline PI614816 & 3.05 & 50.3 & 82.6 & 79.3 & 7.8 & 3.5 & 3.0 \\
\hline PI614817 & 2.35 & 53.6 & 81.7 & 95.0 & 13.3 & 0.0 & 9.0 \\
\hline PI614818 & 2.58 & 49.2 & 81.3 & 85.8 & 9.8 & 3.5 & 0.9 \\
\hline Red Siberian & 3.76 & 48.9 & 77.6 & 88.5 & 10.6 & 2.5 & 2.4 \\
\hline LSD 0.05 & 0.57 & 2.8 & 2.6 & 7.1 & 1.4 & 0.4 & 1.4 \\
\hline
\end{tabular}

$\dagger$ A 0-to-9 visual rating scale was used, with a score of 0 indicating no disease lesions and a score of 9 indicating lesions covering at least $90 \%$ of the leaf surface.

parental cultivar was PI614815 at $3.79 \mathrm{Mg} \mathrm{ha}^{-1}$ and the lowest yielding was PI614817 at $2.35 \mathrm{Mg} \mathrm{ha}^{-1}$ (Table 2). The ranges for days to heading and maturity among the parental cultivars were 13.3 and 16.9 d, respectively; Red Siberian was the earliest cultivar for both maturity traits and Golden German the latest. Thus, most of the varietal differences in maturity were predictable from differences in days to heading. Plant height ranged from 79 to $100 \mathrm{~cm}$ and spike length from 7.8 to $14.4 \mathrm{~cm}$. Two of the parental cultivars did not tiller, whereas the others ranged from 2.5 to 3.5 tillers per plant. One cultivar, PI614817, exhibited an extremely sensitive response to Helminthosporium leaf spot, scoring a 9 in each replication of both environments. All other parental cultivars had low to moderately low disease scores.

\section{Heterosis, Grain Yield}

In the across environmental analysis, the additive effect, average heterosis, and variety heterosis were highly significant, whereas specific heterosis was not significant. The deviation from a model with only the additive effect, average heterosis, and variety heterosis was not significant.

The ranking of the cultivars by the values of $a_{i}$ (Table 3 ) was similar but not identical to the ranking based on per se yields. PI614815, the cultivar with the highest per se yield, also had the most positive value of $a_{i}$. The most noticeable discrepancy between per se yields and $a_{i}$ values was observed for the Red Siberian, Golden German, and PI614814 cultivars. Red Siberian had a highly significantly greater per se grain yield than either of the other two cultivars $\left(3.76 \mathrm{Mg} \mathrm{ha}^{-1}\right.$ compared to
2.54 and $2.75 \mathrm{Mg} \mathrm{ha}^{-1}$ ), but all three varieties had identical and significantly positive values of $a_{i}$.

The significance of $\bar{h}$ was a result of the higher average grain yield of the $F_{2}$ and $F_{3}$ generations compared to the average yield of the parental cultivars (Table 4). The yield superiority of the $\mathrm{F}_{2}$ over the parental generation was $32 \%$, and in 18 of 21 crosses the $\mathrm{F}_{2}$ exhibited high-parent heterosis for yield. In half of these 18 crosses, over-dominance was observed even at the $F_{3}$ generation. The expected yield of the $\mathrm{F}_{1}$ generation was $4.98 \mathrm{Mg} \mathrm{ha}^{-1}$. This was $68 \%$ greater than the average grain yield of the parental cultivars and $31 \%$ greater than the yield of the highest yielding parent.

Varieties Golden German, PI614814, and PI614817 had $h_{i}$ values that were highly significantly greater than 0 (Table 3). The cross between Golden German and PI614814 had $\mathrm{F}_{2}$ high-parent heterosis of $78 \%$, and this $\mathrm{F}_{2}$ was the highest yielding entry in the test at $4.90 \mathrm{Mg}$ $\mathrm{ha}^{-1}$. The estimated yield of the $\mathrm{F}_{1}$ of this cross was 7.29 $\mathrm{Mg} \mathrm{ha}{ }^{-1}$, which was more than twice the yield of the higher parent. The two varieties with the highest per se grain yields, PI614815 and Red Siberian, both had $h_{i}$ values that were highly significantly less than 0 . The $F_{2}$ derived from the cross of these two varieties actually had less grain yield than either parent. The relationship between the level of heterosis observed for grain yield and the coancestry of the parents could not be determined because the phylogenetic relationships among the parents used in this research is not known.

\section{Heterosis, Other Traits}

For all other traits, the relative importance of additive effects was much greater than observed for grain yield.

Table 3. Estimates of additive $\left(a_{i}\right)$ and variety heterosis $\left(h_{i}\right)$ effects for four traits of foxtail millet evaluated in five environments in

1996. In an analysis of variance (Table 1), both the additive and variety heterosis sources of variation were highly significant for each trait.

\begin{tabular}{|c|c|c|c|c|c|c|c|c|c|c|}
\hline \multirow[b]{2}{*}{ Parental cultivar } & \multicolumn{2}{|c|}{ Grain yield } & \multicolumn{2}{|c|}{ Days to heading } & \multicolumn{2}{|c|}{ Days to maturity } & \multicolumn{2}{|c|}{ Plant height } & \multicolumn{2}{|c|}{ Spike length } \\
\hline & $a_{i \dagger} \dagger$ & $\boldsymbol{h}_{i} \dagger$ & $a_{i}$ & $\boldsymbol{h}_{i}$ & $a_{i}$ & $\boldsymbol{h}_{i}$ & $a_{i}$ & $\boldsymbol{h}_{i}$ & $a_{i}$ & $\boldsymbol{h}_{i}$ \\
\hline & $-\mathbf{M}$ & -1 & & 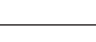 & & & & - c & & \\
\hline Golden German & $0.22 *$ & $0.77 * *$ & 8.0** & $-\mathbf{2 . 8} * *$ & $7.9 * *$ & $-3.0 *$ & $5.6^{* *}$ & -2.3 & $3.6^{* *}$ & -0.2 \\
\hline PI614814 & $0.22 *$ & $\mathbf{0 . 7 5} * *$ & $6.6^{* * *}$ & $-2.1 *$ & $3.2 * *$ & $-4.0 * *$ & $14.0 * *$ & $8.3^{* * *}$ & $1.0 * *$ & $4.6 * *$ \\
\hline PI614815 & $0.33 * *$ & $-0.71 * *$ & $-1.4 * *$ & $2.6 *$ & $-1.8 * *$ & $2.4^{*}$ & 0.1 & $-7.7 *$ & $-\mathbf{3 . 2} * *$ & $-3.5^{* *}$ \\
\hline PI614816 & -0.04 & 0.28 & 0.3 & $5.4 * *$ & $1.0 *$ & $3.2 * *$ & $-16.5 * *$ & -1.2 & $-3.1 * *$ & 0.7 \\
\hline PI614817 & $-0.24 *$ & $0.72 * *$ & $-5.4 * *$ & $-4.5 * *$ & $-2.5 * *$ & 0.6 & $12.6 * *$ & $15.4^{* * *}$ & $5.7 * *$ & $5.1 * *$ \\
\hline PI614818 & $-\mathbf{0 . 7 0} * *$ & $-0.77 * *$ & $-4.8 * *$ & $-\mathbf{2 . 3} *$ & $-3.1 * *$ & $-2.6^{*}$ & $-6.4^{* *}$ & -2.4 & $-2.3 * *$ & $-3.3 * *$ \\
\hline Red Siberian & $\mathbf{0 . 2 2} *$ & $-1.05 * *$ & $-3.2 * *$ & 3.6** & $-4.6^{* *}$ & $3.5^{* *}$ & $-9.3 * *$ & $-10.1^{* *} *$ & $-1.7 * *$ & $-3.4^{* *}$ \\
\hline Std. err. & 0.10 & 0.25 & 0.5 & 1.1 & 0.5 & 1.2 & 1.3 & 3.1 & 0.2 & 0.6 \\
\hline
\end{tabular}

* Significant at the 0.05 level of probability.

** Significant at the 0.01 level of probability.

$\uparrow a_{i}$ and $h_{i}$ are defined by Gardner and Eberhart (1966). 
Table 4. Generational means and estimate of average heterosis $(h)$ for seven agronomic traits of foxtail millet. Reaction to leaf spot disease was evaluated in two environments in 1996, and all other traits were evaluated in five environments in 1996.

\begin{tabular}{|c|c|c|c|c|c|c|c|}
\hline Generational mean & Grain yield & $\begin{array}{l}\text { Days to } \\
\text { heading }\end{array}$ & $\begin{array}{l}\text { Days to } \\
\text { maturity }\end{array}$ & $\begin{array}{c}\text { Plant } \\
\text { height }\end{array}$ & $\begin{array}{l}\text { Spike } \\
\text { length }\end{array}$ & $\begin{array}{c}\text { Tillers } \\
\text { per plant }\end{array}$ & $\begin{array}{l}\text { Reaction to } \\
\text { leaf spot } \\
\text { disease }\end{array}$ \\
\hline & $\mathrm{Mg} \mathrm{ha}^{-1}$ & 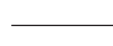 & - & 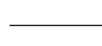 & 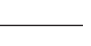 & number & score $\dagger$ \\
\hline Parental & 2.97 & 54.3 & 84.2 & 91.9 & 10.7 & 2.1 & 2.7 \\
\hline $\mathbf{F}_{2}$ & 3.94 & 50.6 & 82.9 & 100.3 & 14.6 & 2.3 & 2.9 \\
\hline $\mathbf{F}_{3}$ & 3.39 & 51.7 & 84.2 & 101.1 & 12.7 & 1.9 & 3.3 \\
\hline LSD 0.05 (Parental vs. F2 or F3) & 0.18 & 0.8 & 0.8 & 2.2 & 0.6 & 0.3 & 0.4 \\
\hline $\bar{h}$ & $2.01 * *$ & $-6.9 * *$ & $-3.4 * *$ & $12.3 * *$ & $7.5^{* *}$ & $0.7 * *$ & -0.1 \\
\hline
\end{tabular}

** Significant at the 0.01 level of probability.

$\dagger$ A 0-to-9 visual rating scale was used, with a score of 0 indicating no disease lesions and a score of 9 indicating lesions covering at least $90 \%$ of the leaf surface.

Only $23 \%$ of the variation among entries was attributable to the additive effect for yield, whereas the minimal value for this same percentage for the other traits was $60 \%$ for spike length and the maximal value was $95 \%$ for leaf spot ratings (Table 1).

Although additivity was the most important effect for each of these other traits, average heterosis was statistically highly significant for each trait except leaf spot rating (nonsignificant), variety heterosis was highly significant for each trait except tiller number and leaf spot rating (nonsignificant), and specific heterosis was highly significant for heading and maturity date, spike length, and leaf spot rating and nonsignificant for plant height and tiller number (Table 1). On the basis of estimates of $\bar{h}$ (Table 4), the expected $\mathrm{F}_{1}$ heterosis was $70 \%$ for increased spike length, $33 \%$ for more tillers, 12 and $4 \%$ for fewer days to heading and maturity, and $13 \%$ for increased plant height. The residual from the full genetic model $\left(a_{i}, \bar{h}, h_{i}\right.$, and $s_{i j}$ effects) was statistically significant for each of the other traits except days to maturity and reaction to Helminthosporium leaf spot (Table 1). The significance of this residual indicated that linkage and/or epistasis were involved in the inheritance of these traits in this material.

The correlation among the $a_{i}$ values between pairs of traits was significant for heading and maturity dates (0.93), plant height and spike length (0.77), and spike length and leaf spot rating (-0.86). Among $h_{i}$ values, significance was observed between heading and maturity dates $(0.78)$, grain yield and plant height $(0.76)$, grain yield and spike length (0.87), and plant height and spike length (0.93). The highest yielding entry, the $F_{2}$ between PI614814 $\times$ Golden German, exhibited high- or earlyparent heterosis not only for yield, but also for each of the other traits except leaf spot rating.

\section{Entry $\times$ Environmental Interaction}

Among the six traits measured at all environments, the percentage of the total sums of squares for environments, entries, and their interaction that was attributable to the environmental main effect ranged from 77 for plant height to 10 for spike length (Table 1). For ratings of resistance to Helminthosporium leaf spot (measured only at E3 and E4), only 3\% of this total of sums of squares was due to the environmental main effect. Over $98 \%$ of the variation among environments for grain yield was attributable to the difference between the irrigated and dryland environments. The aver- age grain yield of the irrigated and dryland environments was 4.86 and $2.70 \mathrm{Mg} \mathrm{ha}^{-1}$, respectively. For the other five traits measured at all environments, the comparison between irrigated and dryland environments was highly significant but was considerably less important than observed for grain yield.

The entry $x$ environmental interaction was highly significant for all traits except reaction to leaf spot disease (Table 1). However, for every trait the interaction was less significant than either main effect. For those traits with a highly significant interaction, the sum of squares attributable to this interaction expressed as a percentage of the sum of squares among entries was greatest for grain yield at 62 . The values of this percentage for days to heading, days to flowering, plant height, spike length, and tillers per plant were $21,32,41,10$, and 9 , respectively.

The most variable of the parental cultivars for grain yield was PI614814, which ranked best among the parents in E4, an irrigated environment, but worst in E3, a dryland environment. The cause of this differential response may not have been water, however, because in the other irrigated environment, E5, this cultivar ranked only fifth best among the parents for grain yield. The best parental cultivar for grain yield across environments, PI614815, ranked either best or second best among the parents for grain yield in each of the five environments. The second best parental cultivar for grain yield, Red Siberian, ranked no worse than third best among the parents in any one of the environments. The entry with the highest average grain yield, the $F_{2}$ from the Golden German $\times$ PI614814 cross, also ranked no worse than third best among all the entries in any environment.

A similar consistency across environments was observed for the grain yield values of the additive and heterotic effects. For example, PI614815, the parental cultivar with the most positive $a_{i}$ value across environments (Table 3 ), had $a_{i}$ values that were significantly greater than zero in three environments and positive in the other two environments. In only one instance did a parental cultivar have an $a_{i}$ value that was significantly positive in one environment and significantly negative in another environment (PI614814 in E4[+] and E5 [-]). Average heterosis was highly significant and positive in every environment. In no instance was a variety heterosis effect for grain yield significantly greater than zero in one environment and significantly less than zero in another environment. 


\section{DISCUSSION}

A primary objective of this research was to determine whether heterosis for grain yield and other important agronomic traits in foxtail millet is of sufficient magnitude to be of practical commercial value. This issue has become more relevant recently because of improved procedures for producing $F_{1}$ seed of this species. The greatest amount of heterosis was observed for grain yield $(67 \%)$ and spike length (68\%). In 18 of 21 crosses, high-parent heterosis for grain yield was observed at the $\mathrm{F}_{2}$ generation. The correlation between pairs of traits among the estimated $a_{i}$ and $h_{i}$ values suggested that at least some of the genes controlling grain yield in foxtail millet are the same as or linked in coupling phase with the genes controlling plant height and spike length.

Our predicted advantage of $\mathrm{F}_{1}$ grain yield over parental yield $\left(2.01 \mathrm{Mg} \mathrm{ha}^{-1}\right)$ may be biased upward if the size of seed from which a plant is produced has an effect on the grain yield of that plant. Seed size was not measured in this research. However, if seed size is dependent on the vigor of the parent plant, then on the basis of the observed heterosis for maturity and plant height, the seed from which the $\mathrm{F}_{2}$ generation was grown would have been the largest seed followed by the $F_{3}$ generation and then the parents. Seed from which the F1 generation would be grown would have the same size as for the parents. The $\mathrm{F}_{2}$ generation had significantly lower seedling emergence than either the $\mathrm{F}_{3}$ generation or the parents (data not shown). In pearl millet, both Gardner (1980) and Lawan et al. (1985) reported a positive association between seed size and seedling emergence. Therefore, it seems unlikely that seed size was related to the vigor of the parent plant in this material. Even if seed size is related to vigor of the parent plant and affects heterosis for grain yield, this advantage could be captured and utilized by growing the F2 or F3 generations.

The heterosis observed for grain yield in this research for foxtail millet was higher than has been reported for other largely self-pollinated cultivated grass species. Eastin et al. (1999) reported in sorghum (Sorghum bicolor L.) $\mathrm{F}_{1}$ heterosis over the average of the parental inbreds for grain yield of 2 to $44 \%$. In both rice (Oryza sativa L.) and wheat, the maximum heterosis for grain yield has been only approximately $20 \%$ (Virmani, 1999; Jordaan et al., 1999). In pearl millet (Pennisetum glaucum L.), which is a cross-pollinated species, the typical advantage in yield of a hybrid over the noninbred parental varieties has been in the range of 20 to $30 \%$ (Axtell et al., 1999). Additional studies should be undertaken to confirm the high level of heterosis for grain yield we observed. Other cultivars of foxtail millet and their crosses should be evaluated, and if possible, yields of $F_{1}$ hybrids should be measured directly rather than estimated. However, even if commercial production of $F_{1}$ hybrids is not economically viable, the level of heterosis we observed for grain yield even at the $\mathrm{F}_{2}$ generation suggests that use of these $F_{2}$ generations or other types of populations with a relatively high percentage of heterozygous genotypes would provide a significant yield benefit over nonhybrid varieties.
Although the entry $\times$ environment interaction was highly significant for six of the seven traits, including grain yield, our results indicated that rankings across environments were relatively consistent. Also, the estimate of average heterosis for grain yield was highly significant in every environment. Thus, testing over many environments may not be necessary to identify the best cultivars or crosses for any of the traits. This conclusion is valid only for the environmental space for which the five environments used in this research are representative.

\section{REFERENCES}

Athwal, D.S., and G. Singh. 1966. Variability in Kangni-1. Adaptation and genotypic and phenotypic variability in four environments. Indian J. Genet. Plant Breed. 26(2):142-152.

Axtell, J., I. Kapran, Y. Ibrahim, G. Ejeta, and D.J. Andrews. 1999. Heterosis in sorghum and pearl millet. p. 375-386. In J.G. Coors and S. Pandey (ed.) The genetics and exploitation of heterosis in crops. ASA, CSSA, and SSSA, Madison, WI.

Baltensperger, D.D. 1996. Foxtail and proso millet. p. 182-190. In J. Janick (ed.) Progress in new crops. ASHS Press, Alexandria, VA.

Darmency, H., C. Quin, and J. Pernes. 1987. Breeding foxtail millet (Setaria italica) for quantitative traits after interspecific hybridization and polyploidization. Genome 29:453-456.

Eastin, J.D., C.L. Petersen, F. Zavala-Garcia, A. Dhopte, P.K. Verma, V.B. Ogunlea, M.W. Witt, V. Gonzalez Hernandez, M. Livera Munoz, T.J. Gerik, G.I. Gandoul, M.R.A. Hovney, and L. Mendoza Onofre. 1999. Potential heterosis associated with developmental and metabolic processes in sorghum and maize. p. 205-220. In J.G. Coors and S. Pandey (ed.) The genetics and exploitation of heterosis in crops. ASA, CSSA, and SSSA, Madison, WI.

Gardner, C.O., and S.A. Eberhart. 1966. Analysis and interpretation of the variety cross diallel and related populations. Biometrics 22: 439-452.

Gardner, J. 1980. The effect of seed size and density on field emergence and yield of perarl millet [Pennisetum americanum (L.) K. Schum.]. M.S. Thesis, Kansas State University, Manhattan.

Gill, A.S., and A.S. Randhawa. 1975. [Setaria italica (L.) P. Beauv.] Heritable variation and interrelationships in foxtail millet. Madras Agric. J. 62(5):253-258.

Gurunadha Rao, Y., M. Anjanappa, and P. Appa Rao. 1984. Genetic variability in yield and certain yield components of foxtail millet (Setaria italica Beauv.). Madras Agric. J. 71(5):332-333.

Haenseler, C.H. 1941. Helminthosporium leaf spot on millet in New Jersey. Plant Dis. Rep. 25:486.

Jordaan, J.P., S.A. Engelbrecht, J.H. Malan, and H.A. Knobel. 1999. Wheat and heterosis. p. 411-421. In J.G. Coors and S. Pandey (ed.) The genetics and exploitation of heterosis in crops. ASA, CSSA, and SSSA, Madison, WI.

Lawan, M., F.L. Barnett, B. Khaleeq, and R.L. Vanderlip. 1985. Seed density and seed size of pearl millet as related to field emergence and several seed and seedling traits. Agron. J. 77:567-571.

Li, H.W., C.J. Meng, and T.N. Liu. 1935. Problems in the breeding of millet (Setaria italica (L.) Beauv.). J. Am. Soc. Agron. 27:963-970.

Malm, R.N., and K.O. Rachie. 1971. Setaria millets: A review of the world literature. S.B. 513. Univ. of Nebraska, Lincoln.

Prasada Rao, G. P., M. Nagaraja Rao, and M. Anjanappa. 1985. Genetic variability in setaria. Andhra Agric. J. 32(1):34-56.

Robert, A.L. 1962. New hosts for three Helminthosporium species from corn. Plant Dis. Rep. 46:321-324.

Senft, D. 1998. Foxtail millet for the Central Plains. Agric. Res. (Washington, DC) 46:22.

Siles, M.M., D.D. Baltensperger, and L.A. Nelson. 2001. [Setaria italica (L.) Beauv.] Technique for artificial hybridizatioof foxtail millet. Crop Sci. 41:1408-1412.

Siles, M.M., D.D. Baltensperger, L.A. Nelson, A. Marcon, and G.E. Frickel. 2001. Registration of five genetic stocks of foxtail millet. Crop Sci. 41:2011-2012.

Singh, G., and D.S. Athwal. 1966. Variability in Kangni-2 genotype $\times$ 
environment interaction, heritability and genetic advance. Indian J. Genet. Plant Breed. 26(2):153-161.

Till-Bottraud, I., X. Reboud, P. Brabant, M. Lefranc, B. Rherissi, F. Vedel, and H. Darmency. 1992. Outcrossing and hybridization in wild and cultivated foxtail millets: Consequences for the release of transgenic crops. Theor. Appl. Genet. 83:940-946.

Virmani, S.S. 1999. Exploitation of heterosis for shifting the yield frontier of rice. p. 423-438. In J.G. Coors and S. Pandey (ed.) The genetics and exploitation of heterosis in crops. ASA, CSSA, and SSSA, Madison, WI.

Vishwanatha, J.K., K.N. Mallanna, K.M. Aradhya, M.V. Channabyre Gonda, and R.U. Shanker. 1981. Genetic variability in a world collection of germplasm of foxtail millet, Setaria italica Beauv. Mysore J. Agric. Sci. 15:234-238.

Wang, T. 1991. Studies and utilization of a high nuclear male sterile line in foxtail millet. J. Hebei Agric. Univ. 14:60-66. 